William Fernie, I tried to contact Mr. Fernie, only to learn that he had died in December, 1956. However, his brother, Peter E. Fernie, wrote to me on December 2, 1958 and I visited him on September 25, 1959, when he was 77 years of age. Peter Fernie settled first in the Rhein district northeast of Yorkton in 1885 and then moved to the Springside district in 1894 . He told me that he had seen only four Whooping Cranes in his lifetime. They were very shy birds, but one year near 1900 a pair resided all summer in the "Fernie meadow", where a ridge runs out into a big marsh, adjacent to Cussed Creek, four miles west and one mile south of the present village of Springside. He saw the cranes dance and heard them "whoop", and they laid a single, large, dirty white egg on a muskrat house. $\mathrm{He}$ said that Sandhill Cranes were scattered throughout the countryside then, and that he had once found two Sandhill Crane nests in the same meadow. This locality is southwest of Springside, whereas that described by William Fernie was northeast of Springside.

Unfortunately, our mosí reliable source of information for the Horseshoe Lake area, the late John A. Gunn, was too young to be out searching for crane nests in 1890. Born in August, 1883 near Fort Qu'Appelle, he was the son of the Donald Gunn mentioned above, and the grandson of the famous Donald Gunn who kept meteorological observations and who collected natural history specimens for the Smithsonian Institute, at the Red River settlement in Manitoba in the 1850's and 1860's.

The Gunns cut hay along the west side of Horseshoe Lake and John, though not quite seven years old, remembered seeing Whooping Cranes there about the spring of 1890 . Sandhill Cranes remained common each summer until about 1896, and he too, found a nest of this species, but Whooping Cranes were not sighted again by the Gunns. Donald Gunn, Jr., left about 1902 and John died August 12 , 1947, but John's wife and daughter Joyce (now Mrs. William Anaka), are still active members of our society and continue to live at their home which is located within a recent extension of Good Spirit Provincial Park.

\title{
SIGHTING OF BAND-TAILED PIGEON IN SOUTH-CENTRAL ALBERTA
}

\author{
by A. E. Barnard, 934 Odlin Rd., Richmond, B.C.
}

On July 10, 1971 the writer and Mr. Kim Hodson were conducting raptor research for the Canadian Wildlife Service in the Hanna area of southcentral Alberta. While driving north on Hwy. 36, approximately $1 \frac{112}{2}$ miles north of the Sheerness turn-off, we observed a large pigeon-like bird flush from the shoulder of the highway and fly to a fence-post, on which it landed. Using $7 \times 35$ binoculars, the following physical characteristics of the bird were noted:

a) general morphology of the domestic Pigeon (Columba livia).

b) bright yellow bill with a black tip.

c) bright yellow feet and legs.

d) metallic-greenish nape bordered posteriorly by a white semi-collar. e) rosy-hued breast and sides.

f) grey back and tail.

g) squarish tail.

All of these are described (Peterson, 1961; Godfrey, 1966) as diagnostic characters of the Band-tailed Pigeon (Columba fasciata). The development of the plumage indicated that it was an adult of this species (G. L. March, personal communication).

Although I was unable to collect or photograph this specimen, there is no doubt on the part of Mr. Hodson or myself as to the validity of this sighting. Both of us normally reside in the Band-tail's recognized range, Mr. Hodson on southern Vancouver Island, and I on the outskirts of Vancouver. Consequently, both of us have the 
opportunity to abserve this handsome bird frequently. In addition, I have hunted this bird almost annually for the last 15 years, and therefore have had many opportunities to observe morphological characteristics close at hand.

The area in which this bird was sighted is largely short-grass prairie, sparsely interspersed with small bluffs of poplars (Populus spp.). According to March (1971), the Band-tailed Pigeon is locally common in southwestern British Columbia and is confined to that area west of the Cascade Mountains.

This $j_{3}$ apparently the third sighting of a Band-tailed Pigeon in Alberta during recent years. A specimen was obtained on July 27, 1967, at Leduc, Alberta, by Mr. Harvey Burns (Spalding and Hampson, 1969). A second sighting was recorded from the foothills country west of Calgary on August 16, 1968 (Wilson, 1968). The status of this species in Alberta is as yet undetermined.

\section{LITERATURE CITED}

Godfrey, W. E. 1966. The birds of Canada. Nat. Mus. Bull. No. 203 - Biol. Ser. No. 73, $428 \mathrm{pp}$.

March, G. L. 1971. The biology of the Bandtailed Pigeon (Columba fasciata) in British Columbia. Ph.D. Thesis, Simon Fraser University.

Peterson, R. T. 1961. A field guide to western birds. Houghton Mifflin. Co., Boston.

Spalding, D. A. E., and M. J. Hampson, 1969. First Alberta record of the Band-tailed Pigeon. Can. Field-Nat. $83: 282-284$

Wilson, M. 1968. New sighting of Band-tailed Pigeon in Alberta. Blue Jay 26:181.

\title{
VARIATION IN DENSITY OF BREEDING DUCKS ACROSS THE ASPEN PARKLANDS AND GRASSLANDS OF CANADA
}

\author{
by Kees Vermeer, Canadian Wildlife Service, Edmonton, Alberta
}

The aspen parklands and grasslands of the Prairie Provinces of Canada contain potholes, marshes and lakes and constitute the major breeding ground for most game duck species in North America. Excluding scoters, eiders, mergansers and oldsquaws, Crissey (1969) estimated that during 1955-64 an average of 47 percent of the North American duck population and 61 percent of the Canadian duck population utilized this region for breeding.

This region has been divided into 10 survey strata (Fig. 1). Table 1 shows the biotic zone and area of each stratum. Stratum 25 is an exception to the other nine strata in that it is in the boreal forest. However, much of the boreal forest has been cleared in this stratum, making it similar for waterfowl observing to those encountered in adjacent parkland. For this reason it has been included here.

In May, surveys are carried out within each stratum to determine the status of waterfowl breeding popula- tions. Average numbers of breeding pairs per square mile during 1960-69 for the 10 survey strata are given for Mallard (Anas platyrhynchos), Pintail (Anas acuta), Gadwall (Anas strepera), American Widgeon (Mareca americana), Shoveler, (Spatula clypeata), Blue - winged Teal (Anas discors), Green-winged Teal (Anas carolinensis), Redhead (Aythya americana), Canvasback (Aythya valisineria), and Lesser Scaup (Aythya affinis).

The purpose of this study was to determine for each species the breeding pair density in each stratum and the preference for a biotic zone.

\section{Methods}

The annual breeding pair surveys have been conducted and published by the U.S. Bureau of Sport Fisheries and Wildlife. Detailed description of the methods used in the waterfowl breeding pair survey is given in the United States Fish and Wildlife Service manual: Standard Procedures for 